Marina Cvetković*

Teacher Education Faculty

University of Belgrade
DOI https://doi.org/10.18485/fid.2019.9.ch18

UDC 159.922.72-053.4:81'243

$371.3:: 811-028.3$

\title{
TEACHING LANGUAGE SKILLS TO YOUNG LEARNERS
}

\begin{abstract}
Summary
Very young learners can understand, visualise and produce words. They adopt whole collocations and language constructions quite spontaneously. Children age 3 and 4 develop listening and speaking skills rapidly, while other skills cannot be developed at this age due to developmental characteristics. Writing is not the skill which can be easily developed at this age and the most children can accomplish is to draw objects, based on what they hear in class. On the other hand, listening and speaking can be developed easily by using different teaching techniques. Very young learners learn pro-actively, they understand quickly, and enjoy every novelty or fun game in class. In addition, they are inquisitive, very eager to experiment and they are inclined to try things repeatedly until they master them. Although the topic of teaching language skills to young learners is wide, the objective of this paper is to point at the possibilities of developing the two skills as supported by theoretical and practical background.
\end{abstract}

Key words: young learners, foreign language, language skills, spoken language, L2 instruction.

\section{Introduction}

Teaching foreign languages is generally a complex process that involves integrated language skills instruction. Listening, speaking, reading and writing are the skills that are developed in this exact order in the process of language acquisition. Children experience language in oral form first, before they are able to produce it. However, these skills cannot be equally developed in very young learners (VYL) and young learners (YL). Very young learners of English are children age 3-7 (age 3-5 in

*_marinacvetkovic@gmail.com 
some countries), the age group which corresponds to preschool children in Serbia. Children age 7-10 fall into the category of young learners. English instruction to both young learners and very young learners must conform to the phases of children's cognitive development. With regard to the cognitive development, theories of three eminent developmental psychologists, Jan Piaget, Lev Vygotsky, and Jerome Bruner, must be considered when developing the syllabi for English language courses. These three psychologists not only offered different perspectives on the significant stages in the children's development, but also explained crucial aspects of their cognitive, mental, and physical growth.

\section{Psychological and developmental theories}

According to Piaget (1896-1980), a Swiss developmental psychologist, children develop and make progress through four stages of cognitive development. At each stage, there are shifts in how children understand the world. Piaget believed that children actively tried to explore the world around them and make sense of it. He developed the stage theory of intellectual development which includes four phases:

-The sensorimotor stage, from birth to age 2;

-The preoperational stage, from age 2 to about age 7;

-The concrete operational stage, from age 7 to 11 ;

-The formal operational stage, which begins in adolescence and spans into cognitive development (in McCarthy, Gallagher and Reid 2002, 58).

Teachers teaching children should be acquainted with the preoperational and concrete operational stages, because the span between 3 and 10 includes very young and young learners. Comprehending developmental characteristics can contribute to better teaching techniques at very early and early age.

Lev Vygotsky (1896-1934) was a Russian developmental psychologist who proposed the bio-social developmental theory which is often referred to as the cultural-historical theory because it is based upon cultural and social interactions. According to Vygotsky, speech is a major psychological tool in a child's development of thinking. As the 
child grows and develops, speech becomes more mature and complex (Vygotsky 1986, 16). Teachers teaching very young and young learners must be aware of this fact, because the speaking skill develops faster in comparison to other skills. Learning a foreign language, in this case English, comes as a natural process which develops in accordance with the complexity of the spoken language. Given that any foreign language is learned for the purpose of communication, this Vygotsky's finding should be taken into account. The major assumptions of his theory are the following (Vygotsky 1986, 127):

- Children develop through informal and formal conversations with adults;

- The first few years of life are critical for development, as this is where thought and language become increasingly independent;

- Complex mental activities begin as basic social activities;

- Children can perform more difficult tasks with the help of a more advanced individual;

- Tasks that are challenging promote cognitive development growth;

- Play is important and allows children to stretch themselves cognitively.

Bearing in mind these statements of Vygotsky, teachers of English should primarily be aware of the basic social activities while performing different tasks. Children should be challenged to do different kinds of activities and tasks, as this will contribute to a better language acquisition, as well as vocabulary and lexical extension.

Jerome Bruner (1915-2016) was an American psychologist whose contribution to human cognitive psychology, cognitive learning theory and educational psychology was immense. According to Bruner, (Bruner $1960,34)$ there are three modes of representation, i.e. the way in which knowledge or information is stored in the memory. These modes are integrated and sequenced. The first mode is Enactive ( $0-1$ years). It stores in the memory the information based on the encoding action. For instance, a baby can remember the previous action of shaking the rattle. This refers to motor responses. In the second, Iconic (1-6 years) mode, information is stored as images (a mental picture in the mind's eye). The last mode, 
Symbolic (7 years and onwards), occurs when information is stored in the form of a code or a symbol, such as language. This form of representation is the most adaptable, as actions and images have a fixed relation to the notions they represent. When teaching English to very young and young learners, the use of realia and pictures must be a part of the process. Children remember images and symbols, they store them in their memory and use them unconsciously and spontaneously.

Maria Montessori (1870-1952) was an Italian physician and educator. She proclaimed natural learning and in her book Absorbent Mind M. Montessori (2007) states that education is a natural process and that it is spontaneously carried out. This book is based on her forty years of experience, observation, and work with children and it represents a landmark of perceiving new educational model. Years after her death, many cognitive and developmental theories proved her findings. When teaching young learners, teachers, should know some of the postulates of this distinguished educator and one of them is that no official system of education considers life itself. Children live in the world of their families, friends, and their interests develop and change. Teaching English should be incorporated into children's world and contemporary surroundings. If we want to apply this to early English language learning, we can say that children should learn in the environment that is familiar and close to them and in the way which suits them best. Natural surroundings and real life situations should be a part of their learning and adopting English as a foreign language.

\section{Pedagogical tasks in acquiring skills}

Teachers of English should be acquainted with the work and theories of Piaget, Vygotsky, Bruner and Montessori because they provide a solid foundation for an understanding and perceiving of children's mental growth, which in turn contributes to a better English language teaching at language courses for young and very young learners. Piagetian and Vygotskyan theories demonstrate that children construct meaning from their own experiences of the world around them. When people speak, their desire is to connect emotionally with other people and communicate with them. We all build up our vocabulary in the process of growing 
up, and this also applies to learning English at the early age. Learning a language is a hard work both for children and adults. Effort is required at every moment and it must be maintained over a long period of time. Meaningfulness is needed in language learning and for the purpose of using authentic language, while many different techniques and procedures must be applied as well. Listening is the most important language skill for young learners. Teachers use listening to familiarize their students with English and to replicate some of the conditions that are present when young learners acquire their first language. Ur $(1984,2)$ defines listening as hearing and understanding the sounds that surround us. This makes it a key element in teaching. Learners get exposed to the language they are learning by listening to it and they gain the tool for interacting with the world that surrounds them.

It is quite clear that listening is a skill that children acquire first, especially if they have not yet learnt to read. When the pupils start to learn a foreign language, it is going mainly through their ears and what pupils hear is their main source of the language. Of course, we also give them as much visual back-up as possible through facial expression, through movement, through mime and through pictures. (Scott and Ytreberg 1996, 21)

There is also the "silent period" in the second language acquisition. This is the period of time when the child or older learner is introduced to the second language and before the time when she or he begins to speak. Due to exposure to the English language, through media and information technologies, children start listening to English at a very early age. When they start learning English at a language school, the "silent period" does not last long.

Maintaining the learners' motivation at a high level is one of the most difficult tasks for teachers. The attention span of young learners is very short and they cannot focus on any task for a longer period of time, which means that the teacher must find the ways to keep them focused on what they have to learn. One of the best ways to keep children motivated is to use games and songs as tools for learning. There should also be different kinds of listening exercises and tasks, which should be adapted to be suitable for the age of the students. However, teachers should not rely on the spoken word only. Listening exercises and activities must be 
planned carefully, depending on the age of children, their attention span, and interests. Listening activities can be effective only if a teacher finds the way to incorporate them into the classroom activities. Sometimes vocabulary is pre-taught before involving children into the activities. Activities should include movement and involve the senses. Plenty of objects, realia, pictures, as well as the surroundings can serve as perfect teaching tools. When children absorb language through play and other activities they find enjoyable, they simultaneously adopt correct grammatical structures. Teachers should note in advance some structures they want to focus on with the children of specific age and engage them to use English actively.

Even when teaching very young and young learners, teachers should be aware of the task-based language instruction.

A pedagogical task is a piece of classroom work that involves learners in comprehending, manipulating, producing or interacting in the target language while their attention is focused on mobilizing their grammatical knowledge in order to express meaning, and in which the intention is to convey meaning rather than to manipulate form. The task should also have a sense of completeness, being able to stand alone as a communicative act in its own right with a beginning, middle and an end. (Nunan 2006, 4)

Pedagogical tasks are mainly focused on communicative language. According to Nunan $(2006,26)$, form is also significant, in the sense that meaning and the form are interrelated. Children should be allowed to speak freely; their grammatical mistakes should not be corrected on the spot, because they could lose confidence. "Polishing" grammar is a delicate task which requires a lot of patience and skills from the part of the teacher.

Reproductive and creative tasks should be included in the syllabi for very young and young learners.

In reproductive tasks learners reproduce language models provided by the teacher, the textbook or the tape. These tasks are designed to give learners mastery of form, meaning and function, and are intended to provide a basis for creative tasks. In creative tasks, learners are recombining familiar elements in novel ways. (Nunan 2006, 37) 
Reproductive tasks refer to speaking and correct pronunciation of the constructions and phrases in English. Listening and speaking skills seem to be inseparable. Children should get used to listening to spoken language and responding in a simultaneous way. If they are exposed to English frequently, they will start using it.

We cannot develop speaking skills unless we also develop listening skills; to have a successful conversation, students must understand what is said to them. Later, the ability to understand the spoken English may become very important (for listening to the radio, understanding foreign visitors, studying, etc.). To develop this activity, students need plenty of practice in listening to English at normal speed. Listening to spoken English is an important way of acquiring the language - of "picking up" structures and vocabulary (Doff 2007, 198).

Learning new words is often understood as learning separate words. However, words should be taught in context, including making sentences, providing responses in a target language, and developing communicative competence in English.

Vocabulary development is about learning words, but it is much more than that. Vocabulary development is also about learning more about those words, and about learning formulaic phrases or chunks, finding words inside them and learning even more about those words. Even the idea of what counts as "word" starts to be confused when linguists try to produce watertight definitions. (Cameron 2001, 73)

Speaking and listening skills can be developed by using different games. There are many different types of games that can be used in the classroom. With the aid of games, children perceive learning English as enjoyable and rewarding. Children cooperate and learn communicative skills through games. According to their language learning focus, games can be classified according to the required resources, as well as the classroom management and organisation needed for their completion. According to Hadfield $(1984,4)$, there are two ways to classify games. The author divides language games into linguistic games and communicative games. Linguistic games focus on accuracy, whereas communicative games focus on the exchange of information and fluency. Lee $(1979,6)$ offers a more detailed classification of games: structure games, vocabu- 
lary games, spelling games, pronunciation games, number games, listenand-do games, read-and-do games, games and writing, mining and roleplay, "language club" games, and discussion games. In addition, there are types of games such as picture games, card and board games, story games, memory games, guessing games, and many others. Some games can be adapted to suit the age and the level of knowledge of young learners and they can contribute to mastering the listening and speaking skills.

Visual aids are also very effective teaching and learning tools in the classroom. As children are very curious and cannot sit still, various activities must be used to keep their attention and maintain their motivation to learn a language. Visual aids are inexpensive and can be easily found and chosen by teachers. They can greatly stimulate young students to learn English. Pictures can be used for presenting different types of vocabulary. Teachers can use pictures from textbooks, magazines, newspapers, some flashcards, and posters. Flashcards should be bright and colourful and they can really be beneficial for learning, especially for students who are visual types. They can be used for different memory games when learning new words or they can be given to children to draw, colour and exchange with peers. Flashcards can also be used for drilling exercises when teachers present new vocabulary and revise the previously taught one. For example, a game Reveal the Word can also be played with flashcards, in which a teacher slowly reveals the card while students are trying to guess what is presented on the card.

Total physical response (TPR) is very important for very young learners. Children learn English through physical responses. Working with children and training teachers proved these statements. Reacting to the simple commands such as "Stand up", "Come on" can be considered as total physical response. For instance, Point or Race to the Flashcards is one among many activities that can be used in the classroom. Various structures can be taught by using visual aids in the way which is amusing and interesting for children.

Content language integrated learning (CLIL) is very useful for teaching very young and young learners. It is hard to distinguish CLIL from standard forms of good practice in the early language learning. This is because the learning topic is often highly authentic for children. They 
are aware that they are learning to listen to and use the sounds and words of another language, while their main focus is on doing - playing, singing, drawing, and building models or other activities. Games and other play-based activities represent a ludic approach where vehicular language is used (Coyle, Hood and Marsh 2010, 16). Contents from other subjects, everyday life situations, arts, crafts or sports can be integrated into learning English.

\section{Conclusion}

Teaching English to very young and young learners is a demanding and challenging task for teachers. Very skilled and motivated teachers can respond to all the demands of this work. Children at a very young age are not literate, they do not know how to read and write. Their exposure to English as a foreign language must be focused primarily on speaking and listening skills, which will eventually evolve into integrated skills.

Speaking and listening are both active uses of language, but differ in the mental activities involved and demands that they make on learners of the language in terms of finding and sharing meaning. Listening can be seen as (primarily) the active use of language to asses other people's meanings, whereas speaking is the active use of language to express meanings so that other people can make sense of them. The labels "receptive" and "productive" uses of language can be applied to listening and speaking respectively (Cameron 2001, 40).

It is necessary for teachers to communicate in a simplified manner when addressing young learners. The simplified language that is used when teaching young learners should be informal, polite, and friendly. Teachers should also be aware of the fact that the process of learning a foreign language is very similar to the process of learning the mother tongue. Language teachers must strive to create a learning-friendly environment that will encourage and motivate the young learners to develop their language skills. 


\section{References}

Bruner, Jerome. 1960. The Process of Education. Harvard: Cambridge, Mass.: Harvard University Press.

Cameron, Lynne. 2001. Teaching English to Young Learners. Cambridge: Cambridge University Press.

Coyle, Do, Philip Hood, and David Marsh. 2010. CLIL Content and Language Integrated Learning. Cambridge: Cambridge University Press.

Doff, Adrian. 2007. Teach English. Cambridge: Cambridge University Press.

Hadfield, Jill. 1984. Elementary Communication Games. London: Nelson.

Lee, William Rowland. 1979. Language Teaching Games and Contents. Oxford: Oxford University Press.

McCarthy Gallagher, Jeanette, and D. Kim Reid. 2002. The Learning Theory of Piaget and Inhelder. Lincoln: iUniverse Press.

Montessori, Maria. 2007. The Absorbent Mind. Redford: Wilder Publications.

Nunan, David. 2006. Task-Based Language Teaching. Cambridge: Cambridge University Press.

Scott, Wendy A., and Lisbeth H. Ytreberg. 1996. Teaching English to Children. London: Longman.

Ur, Penny. 1984. A Course in Language Teaching. Cambridge: Cambridge Teacher Training and Development, Cambridge University Press

Vygotsky, Lev. 1986. Thought and Language. Cambridge: MIT Press. 


\section{Marina Cvetković}

\section{POUČAVANJE DECE NA RANOM UZRASTU JEZIČKIM VEŠTINAMA}

\section{Sažetak}

Deca na veoma ranom uzrastu mogu stvoriti sliku reči, razumeti je i izgovoriti. Potpuno spontano, ona usvajaju cele kolokacije i jezičke konstrukcije. Kod dece uzrasta 3-4 godine, veštine slušanja i govora brzo se razvijaju, dok se ostale jezičke veštine ne mogu razviti na ovom uzrastu zbog odgovarajućih razvojnih karateristika. $\mathrm{Na}$ ranom uzrastu, veština pisanja se ne može jednostavno razviti i ono što ta deca najviše postižu jeste crtanje predmeta koje čuju na času. Zbog toga se u ovom radu usredsređujemo uglavnom na veštine slušanja i govora. Ove dve veštine mogu se jednostavno razviti uz pomoć razičitih tehnika poučavanja. Deca na veoma ranom uzrastu uče proaktivno. Ona su u stanju da brzo razumeju i uživaju u svakoj novini ili u nekoj zabavnoj igri na času. Deca su i radoznala, spremna da eksperimentišu i nastoje da ponavljaju iznova ono što im je nepoznato, sve dok to ne usavrše. Iako je tema poučavanja jezičkim veštinama dece na veoma ranom uzrastu široka, cilj ovog rada je da ukaže na mogućnosti razvoja dve veštine, što je potkrepljeno teorijskim i praktičnim navodima. Stoga smatramo da je neophodno da se nastavnici stranih jezika u predškolskom uzrastu oslanjaju na potvrđena teorijska znanja i primere dobre prakse.

Ključne reči: deca na ranom uzrastu, strani jezik, jezičke veštine, govorni jezik, poučavanje stranog jezika, obrazovanje. 